B I O S C I E N C E

J O U R N A

\title{
YIELD AND PHOSPHORUS USE EFFICIENCY OF CARROT CULTIVARS
}

\author{
CULTIVARS
}

Priscila Maylana Modesto de JESUS ${ }^{1}$ (D), Leilson Costa GRANGEIRO2 (iD,
Valdívia de Fátima Lima de SOUSA
(i), Gerlani Alves da SILVA Luiz Ricardo Rebouças da SILVA ${ }^{5}$ iD , Gardênia Silvana de Oliveira RODRIGUES ${ }^{6}$ (D)

\footnotetext{
${ }^{1}$ Postgraduate Program in Agronomy, Federal Rural University of the Amazon, Belém, Pará, Brazil.

2 Department of Agronomic and Forestry Sciences, Federal Rural University of the Semi-Arid, Mossoró, Rio Grande do Norte, Brazil.

${ }^{3}$ Agrícola Famosa, Mossoró, Rio Grande do Norte, Brazil.

${ }^{4}$ Postgraduate Program in Phytotechnics, Federal University of Rural do Semi-Arid, Mossoró, Rio Grande do Norte, Brazil.

${ }^{5}$ Postgraduate Program in Soil and Water Management, Federal Rural University of the Semi-Arid, Mossoró, Rio Grande do Norte, Brazil.

${ }^{6}$ Federal Rural University of the Semi-Arid, Mossoró, Rio Grande do Norte, Brazil.
}

Corresponding author:

Leilson Costa Grangeiro

Email: leilson@ufersa.edu.br

How to cite: JESUS, P.M.M., et al. Yield and phosphorus use efficiency of carrot cultivars. Bioscience Journal. 2021, 37, e37085. https://doi.org/10.14393/BJ-v37n0a2021-54095

\begin{abstract}
Phosphate fertilization is indispensable for carrot cultivation, as it contributes to plant development, formation of marketable roots and higher yields. In this context, the objective of this study was to evaluate the production and nutritional efficiency of carrot cultivars under phosphate fertilization. The experiments were carried out from July to November 2016 and from June to October 2017, at the Rafael Fernandes experimental farm, District of Alagoinha, Mossoró, RN, Brazil. The experimental design was in randomized blocks, in a $4 \times 4$ factorial scheme with 4 replicates. The treatments consisted of the combination of carrot cultivars (Brasília, Planalto, Suprema and Nativa) with phosphorus $(P)$ doses $\left(0,90,180\right.$ and $\left.270 \mathrm{~kg} \mathrm{ha}^{-1} \mathrm{P}_{2} \mathrm{O}_{5}\right)$. The characteristics analyzed were: $\mathrm{P}$ content in the diagnostic leaf, plant dry matter, plant height, marketable and total yields, and the classification of cultivars for efficiency and response to phosphate fertilization. The increments promoted by phosphate fertilization were $64 \%$ in plant height, $444 \%$ in dry matter and $284 \%$ in marketable yield. The maximum marketable yield was obtained with doses from 186.8 to $243.5 \mathrm{~kg} \mathrm{ha}^{-1}$, depending on the cultivar. The Native cultivar was classified as more efficient in the use of P.
\end{abstract}

Keywords: Daucus Carota L. Phosphorus. Plant Nutrition. Yield

\section{Introduction}

Carrot (Daucus carota) is among the ten most cultivated vegetables in Brazil, with a consumption of $5.8 \mathrm{~kg}$ per capita per year (Zanfirov et al. 2012). The annual Brazilian production is approximately 752,000 tons, being the fourth most important vegetable in commercialized volume and the fifth in economic value (CNA 2017). Carrots stand out from other vegetables for containing a large amount of vitamin C, vitamin $E$, fibers and minerals such as potassium, phosphorus, calcium, magnesium and iron (Resende and Braga 2014).

Phosphorus is the fourth most absorbed nutrient by carrot and the third most exported (Cecilio Filho and Peixoto 2013; Dezordi et al. 2015). Deficiency of this nutrient negatively alters yield, as it also reduces the absorption of other nutrients (Flores et al. 2012). However, its excess can reduce the availability of metallic micronutrients, such as Zn (Drissi et al. 2015; Ova et al. 2015). It is one of the most used in the carrot fertilization program, due to its importance in plant metabolism, being essential in plant establishment and 
development, because it favors the root system, increasing the absorption of water and nutrients, resulting in significant increments in root yield (Avalhães et al. 2009; Nascimento et al. 2017).

In carrot cultivation, fertilization significantly contributes to the revenue and cost of production, so adequate nutritional management is necessary for the economic success of cultivation. Most of the current official fertilizer recommendations can be considered outdated, as the expected yields are lower than those currently obtained. Changes that occurred in the production system with the incorporation of new technologies, such as the introduction of more productive hybrids, denser plantations, fertigation, among others, significantly increased crop yield. This new expected yield combined with product quality requires further research on nutrition and fertilization, in order to meet the needs of the crop, providing nutrients for the plant in a balanced way.

In relation to the capacity of carrot crop to respond to phosphate fertilization, research is still limited. The combined application of plant residues with phosphate fertilization promoted higher production of fresh matter of marketable roots and also reduced mass losses during storage (Araújo et al. 2004). Pelá et al. (2018) observed increments in plant height, root length and yield of carrot, in addition to the improvement in commercial standards of roots with the use of phosphate fertilizer.

Regarding carrot cultivars, the commercial standard of roots of the cultivar Brasilia, preferred by the Brazilian consumer market, and its resistance to leaf burning enabled the advance of the crop in the summer season in the various regions of the country and also the stabilization of carrot supply all over the national territory. In recent years, the cultivar Brasilia and all its selections have been replaced with hybrids of high production potential and with high-quality roots. However, these hybrids are developed abroad and are not always adapted to the cultivation conditions of the Brazilian carrot-producing regions, and it is indispensable for companies to conduct pre-evaluations together with producers to avoid failures and economic losses (Melo and Araújo 2016).

Therefore, the objective of this study was to evaluate the yield and phosphorus use efficiency of carrot cultivars, under phosphate fertilization.

\section{Material and Methods}

The experiments were carried out at the Rafael Fernandes Experimental Farm of the Federal Rural University of the Semi-Arid Region, located in the district of Alagoinha, $20 \mathrm{~km}$ away from the municipality of Mossoró-RN, Brazil ( $5^{\circ} 03^{\prime} 37^{\prime \prime} \mathrm{S} ; 3^{\circ} 23^{\prime} 50^{\prime \prime} \mathrm{W} ; 72 \mathrm{~m}$ ), in soil classified as Argissolo Vermelho Distrófico típico (Ultisol) (Rego et al. 2016), in the periods from July to November 2016 (Period 1) and June to October 2017 (Period 2).

In the experimental areas, soil samples were collected in the $0-20 \mathrm{~cm}$ layer for chemical characterization, whose results for Periods 1 and 2 were respectively: $\mathrm{pH}\left(\mathrm{H}_{2} \mathrm{O}\right)=5.9$ for both periods; $\mathrm{EC}=$ 0.02 and $0.07 \mathrm{dS} \mathrm{m}^{-1} ; \mathrm{P}=1.4$ and $6.3 \mathrm{mg} \mathrm{dm}^{-3} ; \mathrm{K}=55.6$ and $50.3 \mathrm{mg} \mathrm{dm}^{-3} ; \mathrm{Na}^{+}=2.3$ and $5.8 \mathrm{mg} \mathrm{dm}^{-3} ; \mathrm{Ca}^{2+}=$ 1.13 and $1.1 \mathrm{cmol}_{\mathrm{c}} \mathrm{dm}^{-3} ; \mathrm{Mg}^{2+}=0.77$ and $0.60 \mathrm{cmol}_{\mathrm{c}} \mathrm{dm}^{-3} ; \mathrm{Al}^{3+}=0.20$ and $0.10 \mathrm{cmol}_{\mathrm{c}} \mathrm{dm}^{-3} ; \mathrm{SB}=1.85$ and 0.97 $\mathrm{cmol}_{\mathrm{c}} \mathrm{dm}^{-3}$.

The experimental design used was in randomized blocks, in a $4 \times 4$ factorial scheme, with four replicates. The treatments consisted of the combination of four carrot cultivars (Brasília, Planalto, Suprema and Nativa) and four doses of phosphorus $\left(0,90,180\right.$ and $270 \mathrm{~kg} \mathrm{ha}^{-1} \mathrm{P}_{2} \mathrm{O}$. The experimental unit consisted of a $2.4 \times 1.0 \mathrm{~m}$ bed, with five rows of plants, spaced by $0.20 \times 0.08 \mathrm{~m}$, totaling an area of $2.4 \mathrm{~m}^{-2}$, considering the three central rows as usable area, disregarding one plant on each end.

Soil tillage consisted of plowing, harrowing and raising of the beds. Fertilization was performed based on soil chemical analysis and recommendation for the crop, according to Cavalcanti (2008), using $75 \mathrm{~kg} \mathrm{ha}^{-1}$ of $\mathrm{N}, 54 \mathrm{~kg} \mathrm{ha}^{-1}$ of $\mathrm{K}_{2} \mathrm{O}, 4 \mathrm{~kg} \mathrm{ha}^{-1}$ of $\mathrm{B}$ and $9 \mathrm{~kg} \mathrm{ha}^{-1}$ of $\mathrm{Zn}$, respectively in the forms of urea, potassium chloride, boric acid and zinc sulfate. Phosphorus was applied entirely at planting, at the doses according to the treatments, in the form of triple superphosphate.

Top-dressing fertilization was performed with $52.5 \mathrm{~kg} \mathrm{ha}^{-1}$ of $\mathrm{N}$ and $57.5 \mathrm{~kg} \mathrm{ha}^{-1}$ of $\mathrm{K}_{2} \mathrm{O}$, in the forms of ammonium sulfate, potassium chloride and potassium nitrate, split and applied at 25 and 45 DAS. The source of micronutrients was a commercial formulation containing $11.6 \% \mathrm{~K}_{2} \mathrm{O}, 1.28 \% \mathrm{~S}, 0.86 \% \mathrm{Mg}, 2.1 \% \mathrm{~B}$, $0.36 \% \mathrm{Cu}, 2.66 \% \mathrm{Fe}, 2.48 \% \mathrm{Mn}, 0.036 \% \mathrm{Mo}$ and $3.38 \% \mathrm{Zn}$, at a dose of $1.0 \mathrm{~kg} \mathrm{ha}^{-1}$, split and applied at 50, 65 and 80 DAS. 
Sowing was performed manually in the transverse direction of the bed, in pits approximately $2.0 \mathrm{~cm}$ deep, spaced by $0.08 \mathrm{~m}$, with 3 to 4 seeds per pit. Thinning was performed at 25 days after sowing (DAS), leaving one plant per pit. Irrigation was applied using a micro-sprinkler system, by placing in the center of the beds one line of micro-sprinklers spaced by $1.20 \mathrm{~m}$ with average flow rate of $30 \mathrm{~L} \mathrm{~h}^{-1}$. Manual weeding was performed when necessary.

Harvest was carried out when the older leaves became yellow and the young ones were slightly arched, which occurred respectively at 120 and 125 DAS, in Periods 1 and 2. The characteristics evaluated were: A) phosphorus content in the diagnostic leaf $\left(\mathrm{g} \mathrm{kg}^{-1}\right)$ : ten young, fully expanded leaves were collected in each plot in the middle of the crop cycle (60 DAS), according to the methodology proposed by Malavolta et al (1997), and P contents were analyzed following the methodology described by Trani and Raij (1997); B) plant height $(\mathrm{cm})$ : determined with a ruler, measuring fifteen plants per plot from the soil level to the tip of the highest leaf, at 90 days after sowing; C) plant dry matter ( plant $^{-1}$ ): at harvest, five plants from the usable area of the plot were collected, washed, placed in paper bags and dried in a forced air circulation oven with temperature regulated at $65 \stackrel{\circ}{\circ}$, until reaching constant weight; D) yield of marketable roots $\left(\mathrm{t} \mathrm{ha}^{-1}\right)$ : determined through the sum of the production of roots longer than $12 \mathrm{~cm}$, free of cracks, bifurcations, nematodes and mechanical injury; $\mathrm{E}$ ) total yield of roots $\left(\mathrm{t} \mathrm{ha}{ }^{-1}\right)$ : determined through the sum of marketable and non-marketable yields.

Classification of cultivars as to their efficiency and response to phosphate fertilization (Fageria and Kluthcouski 1980). The index of response (IR) was obtained by the difference between the yields of the crop with application of $180 \mathrm{~kg} \mathrm{ha}^{-1}$ of $\mathrm{P}_{2} \mathrm{O}_{5}$ and without $\mathrm{P}$ application, divided by the difference between $\mathrm{P}$ doses.

The classification of cultivars was performed through graphic representation on the Cartesian plane. The yield of roots obtained without $P$ application is on the $X$-axis, and the index of response is on the $Y$-axis. The point of origin of the axes is the average yield of cultivars without $P$ application and the average index of response. Efficient and responsive cultivars are represented in the first quadrant; inefficient and responsive cultivars in the second; inefficient and non-responsive cultivars in the third; and efficient and non-responsive cultivars in the fourth.

The analyses of variance for the evaluated characteristics were performed separately for each experiment. Then, the experiments were jointly analyzed using the program Sisvar v5.3. (Ferreira 2014). Regression analysis was performed for the quantitative factor ( $\mathrm{P}$ doses) and Tukey test at 5\% probability level was applied for the qualitative factor (cultivars).

\section{Results and Discussion}

The interaction between cultivar, $\mathrm{P}$ dose and period factors was significant for leaf $\mathrm{P}$ content, plant dry matter and total yield. Marketable yield was significantly affected by the interactions between cultivar and $\mathrm{P}$ dose, period and cultivars. For plant height, there were significant single effects of cultivar and $\mathrm{P}$ dose.

Phosphorus content in the diagnostic leaf was described by a linear regression model, in Period 1 , in all carrot cultivars. The estimated maximum values were 5.6, 5.2, 5.5 and $5.5 \mathrm{~g} \mathrm{~kg}^{-1}$, respectively, for the cultivars Brasília, Nativa, Planalto and Suprema (Figure 1A). In Period 2, the P contents were described by a linear model for Planalto and a quadratic model for Suprema, with maximum values of 4.7 and $5.4 \mathrm{~g} \mathrm{~kg}^{-1}$ obtained at $\mathrm{P}_{2} \mathrm{O}_{5}$ doses of 270 and $156.8 \mathrm{~kg} \mathrm{ha}^{-1}$ (Figure 1B). No mathematical model fitted to the data of the cultivars Brasília and Nativa, which had averages of 4.3 and $4.5 \mathrm{~g} \mathrm{~kg}^{-1}$, respectively.

Indicating that the phosphorus applied to the soil showed positive results in the leaf tissue, since the leaf $P$ contents, regardless of $P$ doses and carrot cultivars in both experiments, were within the appropriate range ( 2 to $4 \mathrm{~g} \mathrm{~kg}^{-1}$ ), according to Trani and Raij (1997). However, in the treatment without P application, plants developed characteristic symptoms of deficiency, such as leaves of purplish brown color, reduced growth and roots with abnormal development, according to Bastos et al. (2008).

Phosphate fertilization was also relevant for potato (Fernandes and Soratto 2016); sweet potato (Cruz et al. 2016) and sugar beet crop (Oliveira et al. 2016), with significant increases in leaf $P$ levels due to phosphate fertilization. Nascimento et al. (2017) did not find significant increases in phosphorus content in the diagnostic carrot leaf, when using doses from 0 to $640 \mathrm{~kg} \mathrm{ha}^{-1}$ of $\mathrm{P}_{2} \mathrm{O}_{5}$, with an average content of $2.7 \mathrm{~g}$ $\mathrm{kg}^{-1}$ of $\mathrm{P}$. 
Deficiency of $\mathrm{P}$ causes significant changes in important physiological processes of the plant, such as reduced respiration and photosynthesis. The reduction of respiration compared with photosynthesis, delays the use of carbohydrates and their accumulation in the leaves, making them darker. Reductions in nucleic acid and protein synthesis may also occur, with accumulations of soluble nitrogen compounds in the tissue. Reductions in plant height, number of leaves, development of the root system, production of dry matter and delay in maturation (Assunção et al. 2016).

A

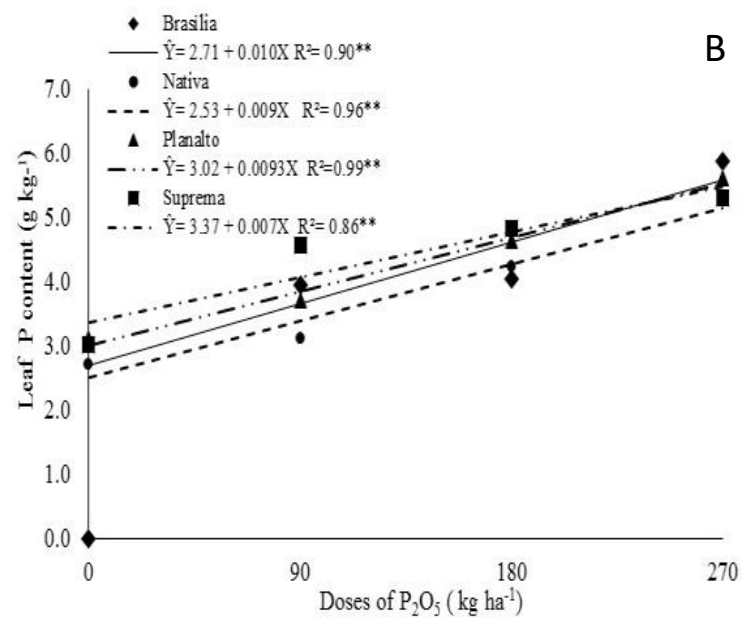

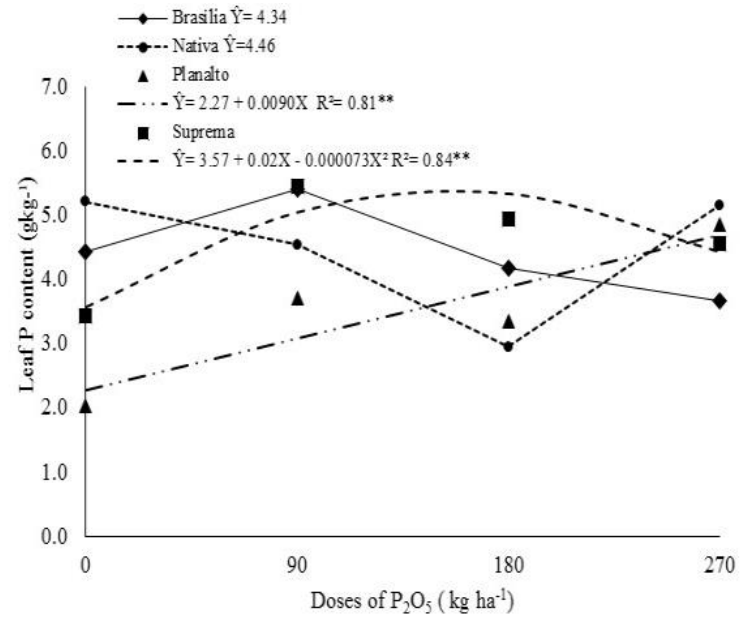

Figure 1. Leaf phosphorus content as a function of phosphorus doses and cultivars in the crops. $A-$ from July to November 2016; B - from June to October 2017.

The plant dry matter (PDM) of the carrot cultivars showed an increasing behavior, as a function of the increment of $\mathrm{P}$ doses in the soil. In Period 1 , the estimated maximum values were obtained at $\mathrm{P}_{2} \mathrm{O}_{5}$ doses of 214.9, 189.9, 220.2 and $270 \mathrm{~kg} \mathrm{ha}^{-1}$, respectively, for the cultivars Brasília, Nativa, Planalto and Suprema (Figure 2A). In Period 2, these doses were 186.4, 212.5, 221.7 and $212.9 \mathrm{~kg}^{-1}$ ha $\mathrm{P}_{2} \mathrm{O}_{5}$ (Figure 2B). These results corroborate those reported by Cecilio Filho and Peixoto (2013), who also obtained increments in carrot PDM, with the increase in $\mathrm{P}$ doses, reaching a maximum of $23.26 \mathrm{~g}$ per plant, with the application of $500 \mathrm{~kg} \mathrm{ha}^{-1}$ of $\mathrm{P}_{2} \mathrm{O}_{5}$.

The mean increments in the PDM of the carrot cultivars, considering the doses that promoted the maximum estimated values, compared to the treatment without P application, ranged from 135 to $444 \%$ in Period 1 and from 174 to $325 \%$ in Period 2. The positive response of carrot regarding PDM possibly occurred due to the rapid availability of nutrients and their absorption by the plant, generating large biomass and consequently greater input of photosynthates that promotes positive effects of this nutrient in the production of crops, especially in characterized tropical soils for low natural fertility.
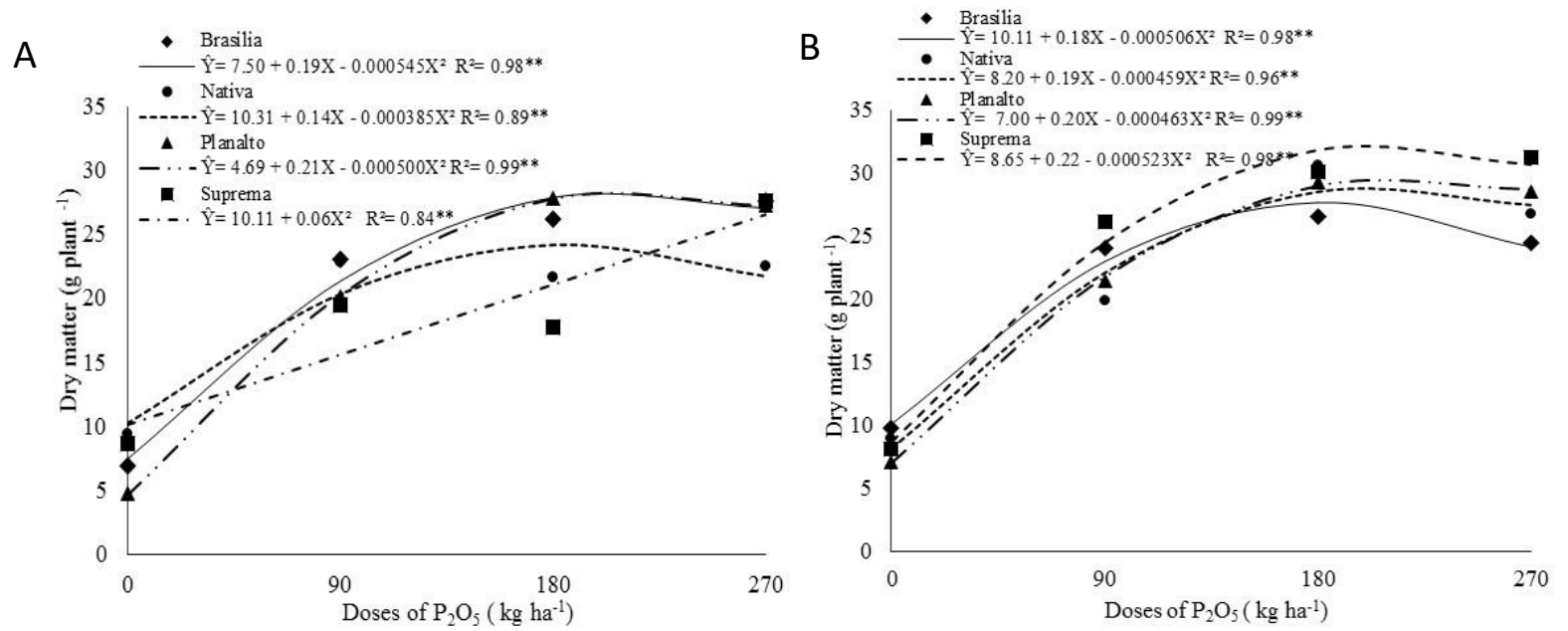

Figure 2. Plant dry matter as a function of phosphorus doses and carrot cultivars in the crops. A - from July to November 2016; B - from June to October 2017. 
Plant height was significantly affected by $P$ doses, being described by the linear regression model (Figure 3A). Maximum plant height was reached with the $\mathrm{P}$ dose of $270 \mathrm{~kg}^{-1}$ ha $\mathrm{P}_{2} \mathrm{O}_{5}$, which led to a value of $50.62 \mathrm{~cm}$, resulting in a $64 \%$ increase compared to the absence of phosphate fertilization. The cultivars Brasília $(41.16 \mathrm{~cm})$, Nativa $(41.72 \mathrm{~cm})$ and Planalto $(43.52 \mathrm{~cm})$ did not differ significantly, being superior to the cultivar Suprema in terms of height $(38.16 \mathrm{~cm})$.

Increased height of carrot plants with phosphate fertilization was also observed by Chaves et al. (2015), in which the dose of $300 \mathrm{~kg} \mathrm{ha}^{-1}$ of $\mathrm{P}_{2} \mathrm{O}_{5}$ provided the greatest height $(47.68 \mathrm{~cm})$. Similarly, Pelá et al. (2018) obtained greater plant height $(55.5 \mathrm{~cm})$ using monoammonium phosphate (MAP) as a source, at a dose of $566.5 \mathrm{~kg} \mathrm{ha}^{-1}$ of $\mathrm{P}_{2} \mathrm{O}_{5}$. When the source was polymer coated MAP, the maximum plant height was $60.1 \mathrm{~cm}$, with a dose of $515.6 \mathrm{~kg} \mathrm{ha}^{-1}$ of $\mathrm{P}_{2} \mathrm{O}_{5}$. These researches show how the crop is responsive to phosphorus application, regardless of the cultivar.

A

B
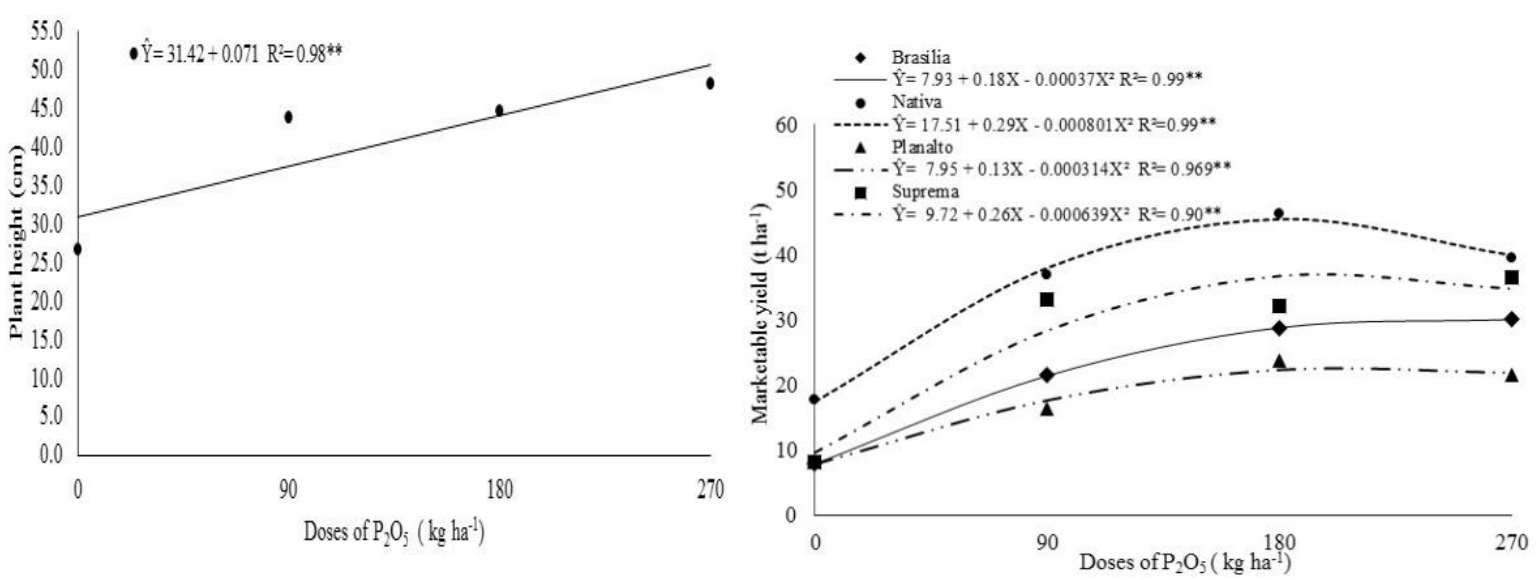

Figure 3. Plant height and marketable yield of carrot as a function of phosphorus doses and cultivars.

A - plant height as a fuction of phosphorus doses; B - marketable yield of carrot as a function of phosphorus doses and cultivares.

The average marketable yield (MY) was significantly described by the quadratic models in all carrot cultivars. The doses that maximized MY were 243.5, 186.8, 217.6 and $208 \mathrm{~kg}^{-1}$ ha ${ }^{-1} \mathrm{P}_{2} \mathrm{O}_{5}$, respectively for the cultivars Brasília $\left(30.3 \mathrm{t} \mathrm{ha}^{-1}\right)$, Nativa $\left(45.5 \mathrm{t} \mathrm{ha}^{-1}\right)$, Planalto $\left(23.7 \mathrm{t} \mathrm{ha}^{-1}\right)$ and Suprema $\left(37.3 \mathrm{t} \mathrm{ha}^{-1}\right)$ (Figure 3B). These doses promoted increments in MY of 282, 160, 198 and 284\%, compared to the values obtained without $\mathrm{P}$ application, respectively in the same order of the cultivars mentioned above.

The increase in $\mathrm{P}$ availability for plants promoted by phosphate fertilization resulted in significant increases in the growth characteristics and yield of carrots. In treatments without addition of phosphorus, the plants produced marketable roots, but with dry matter and reduced diameters when compared to the other treatments.

According to Péret et al. (2011), under conditions of low phosphorus content in the soil, root system architecture could be greatly altered, leading to a shallower root system bearing more and longer lateral roots as well as denser root hairs. Generally, larger root systems with larger root-surface area, are closely associated with greater P uptake efficiency when the soil P concentration is low (Hu et al. 2010).

Chaves et al. (2015) also found quadratic behavior when determining the adequate $P$ dose for carrot cultivation in the microregion of Chapadinha, MA, reaching the estimated marketable production of $25.24 \mathrm{t}$ $\mathrm{ha}^{-1}$ with the application of $200 \mathrm{~kg} \mathrm{ha}^{-1}$ of $\mathrm{P}_{2} \mathrm{O}_{5}$.

The cultivar Nativa was superior to the others in terms of $M Y$, in the absence of phosphate fertilization, and did not differ significantly from Suprema at $\mathrm{P}_{2} \mathrm{O}_{5}$ doses of 90 and $270 \mathrm{~kg} \mathrm{ha}^{-1}$ and did not differ from Brasília at the $\mathrm{P}_{2} \mathrm{O}_{5}$ dose of $180 \mathrm{~kg} \mathrm{ha}^{-1}$ (Table 1).

Regarding the periods, the cultivar Nativa stood out, but did not differ significantly from Planalto (Period 1) and Suprema (Period 2) (Table 1). The higher marketable yield obtained in Period 2 may be related to climatic conditions, as it corresponded to the coldest season, when temperatures of 26 ㅇ $\mathrm{C}$ were recorded at 50 DAS (secondary growth stage), slowly increasing to $28{ }^{\circ} \mathrm{C}$ until the end of the cycle. In relation to Period 1 , there were temperatures of $27.5 \circ \mathrm{C}$ (at $50 \mathrm{DAS}$ ), reaching $29{ }^{\circ} \mathrm{C}$ until harvest. Another possibility would 
be the amounts of $P$ found in the soil before planting, which were equal to $1.4 \mathrm{mg} \mathrm{dm}^{-3}$ and $6.3 \mathrm{mg} \mathrm{dm}^{-3}$ for Periods 1 and 2, respectively.

Table 1. Marketable yield of carrots as a function of phosphorus doses, cultivars, and growing periods.

\begin{tabular}{ccccccc}
\hline \multirow{2}{*}{ Cultivar } & \multicolumn{3}{c}{ Dose $\left(\mathrm{kg} \mathrm{ha}^{-1}\right)$} & \multicolumn{2}{c}{ Periods } \\
\cline { 2 - 6 } & 0 & 90 & 180 & 270 & 1 & 2 \\
\hline Brasília & $7.90^{\mathrm{b}}$ & $21.56^{\mathrm{b}}$ & $28.70^{\mathrm{ab}}$ & $30.12^{\mathrm{b}}$ & $16.32^{\mathrm{Bc}}$ & $27.82^{\mathrm{Ab}}$ \\
Nativa & $17.83^{\mathrm{a}}$ & $37.02^{\mathrm{a}}$ & $46.37^{\mathrm{a}}$ & $39.60^{\mathrm{a}}$ & $35.97^{\mathrm{Aa}}$ & $34.44^{\mathrm{Aa}}$ \\
Planalto & $8.44^{\mathrm{b}}$ & $16.28^{\mathrm{b}}$ & $23.30^{\mathrm{b}}$ & $21.49^{\mathrm{C}}$ & $16.08^{\mathrm{Ac}}$ & $18.94^{\mathrm{Ac}}$ \\
Suprema & $8.19^{\mathrm{b}}$ & $33.08^{\mathrm{a}}$ & $32.23^{\mathrm{b}}$ & $36.43^{\mathrm{ab}}$ & $25.18^{\mathrm{Bb}}$ & $29.78^{\mathrm{Aab}}$ \\
\hline
\end{tabular}

*Means followed by the same lowercase letter in the column do not differ statistically and means followed by the same uppercase letter in the row do not differ statistically by the Tukey test.

The total yield (TY) as a function of $P$ doses was described by a quadratic regression model, with highest yield obtained by the cultivar Nativa, both in Period $1\left(47.13 \mathrm{t} \mathrm{ha}^{-1}\right)$ and in Period $2\left(55.42 \mathrm{t} \mathrm{ha}^{-1}\right)$ at the estimated maximum doses of 170.2 and $209.6 \mathrm{~kg} \mathrm{ha}^{-1}$ of $\mathrm{P}_{2} \mathrm{O}_{5}$ (Figure $4 \mathrm{~A}$ and $4 \mathrm{~B}$ ). For the other cultivars in Period 1, the doses were 183.8, 251.5 and $195 \mathrm{~kg} \mathrm{ha}^{-1}$ of $\mathrm{P}_{2} \mathrm{O}_{5}$ for Suprema (39.64 t ha-1), Brasília ( $37.40 \mathrm{t}$ $\mathrm{ha}^{-1}$ ) and Planalto (35.59 $\mathrm{t} \mathrm{ha}^{-1}$ ), respectively (Figure 4A). In Period 2, the maximum estimated doses were 212.4, 201.6 and 190.4 for Suprema (54.90 $\mathrm{t} \mathrm{ha}^{-1}$ ), Planalto (52.93 t ha-1) and Brasília (50.66 t ha ${ }^{-1}$ ), respectively (Figure 4B).

In all carrot cultivars there were reductions in TY, with the application of $\mathrm{P}$ in higher doses. Possibly, there was an increase in the salinity of the soil near the root zone of the plant and a consequent reduction in the absorption of other cations. According to Alves et al (2011), high salinization affects the growth and distribution of plant roots, as well as the absorption of water and nutrients, since the accumulation of mineral salts reduces the osmotic potential close to the rhizosphere, causing a nutritional imbalance configuring a zone prone to luxury consumption or toxicity by $\mathrm{P}$.

A

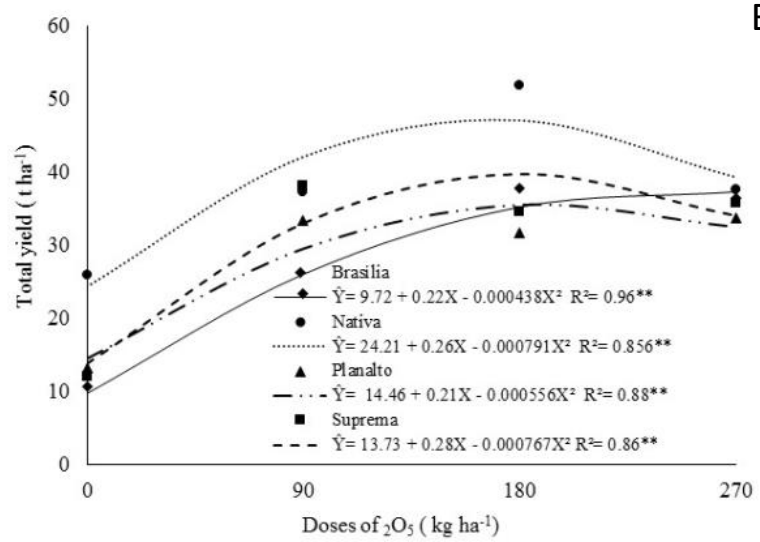

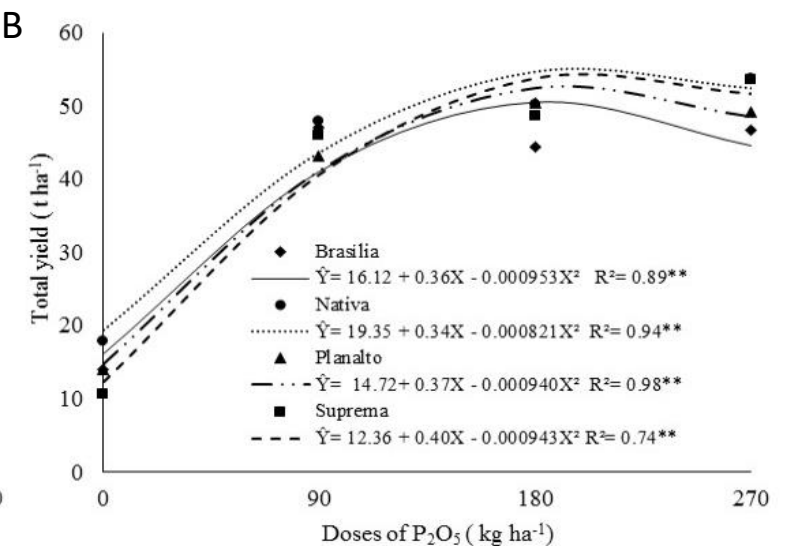

Figure 4. Total yield of roots as a function of phosphorus doses and carrot cultivars in the crops. A - from July to November 2016; B - from June to October 2017.

Maximum TY values were 285, 122, 146 and 188\% higher than those obtained without P application, respectively for the cultivars Brasília, Nativa, Planalto and Suprema in Period 1. In this same order of cultivars, the increments in Period 2 were 214, 186, 260 and 344\%. With the exception of the cultivar Nativa, the doses that maximized TY were above the recommended for carrot crop, according to Cavalcanti (2008), for soils with low $P$ content $\left(<11 \mathrm{mg} \mathrm{dm}^{-3}\right)$, used as a reference in this study.

Crop responses to phosphate fertilization are more significant in soils with low fertility, as $\mathrm{P}$ stimulates root development, consequently increasing nutrient absorption and increasing crop production (Cavalcante et al. 2017). It also favors the accumulation of starch, sugars, and tuberous root size, improving root quality (Oliveira et al. 2005).

In the classification of cultivars regarding efficiency and response to phosphate fertilization, the cultivar Nativa was classified as efficient and responsive in terms of $\mathrm{P}$ use, indicating that it has greater 
resilience capacity compared to the others, as it produced above average under conditions of low $P$ level and also responded positively to the application of $180 \mathrm{~kg} \mathrm{ha}^{-1}$ of $\mathrm{P}_{2} \mathrm{O}_{5}$ in the soil, increasing its yield (Figure 5).

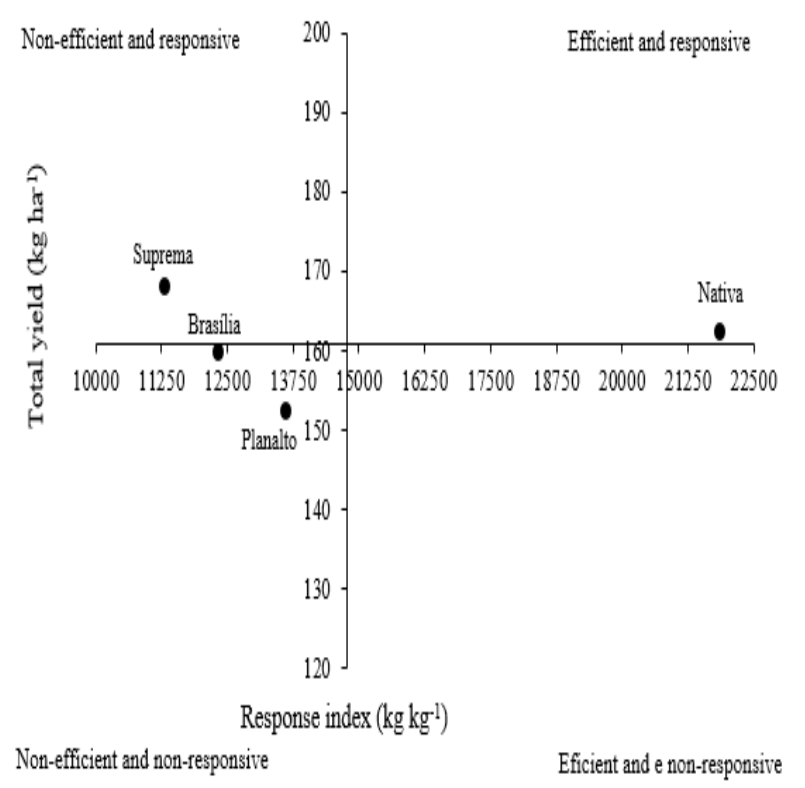

Figure 5. Efficiency in the use and response to the application of phosphorus for the yield of carrot cultivars.

The cultivar Suprema was classified as inefficient, but responsive, indicating that it produces little under conditions of low P level in the soil, but responds well to fertilization with this nutrient (Figure 4). For this cultivar, phosphate fertilization promoted a significant increase in yield. The cultivar Suprema obtained lower TY in the environment with low $\mathrm{P}$ content (control), but its TY increased by $330 \%$ when compared to the control, with application of $180 \mathrm{~kg} \mathrm{ha}^{-1}$ of $\mathrm{P}_{2} \mathrm{O}_{5}$, besides obtaining a higher index of response, with an increment of $168 \mathrm{~kg}$ of carrot roots for each kilogram of $P$ applied (Figure 5).

The cultivars Brasília and Planalto were classified as inefficient and non-responsive, because they produced below the average of the environment with low $\mathrm{P}$ level and also have indices of response lower than the average of the cultivars, because even with phosphate fertilization ( $180 \mathrm{~kg} \mathrm{ha}^{-1}$ of $\mathrm{P}_{2} \mathrm{O}_{5}$ ), it was not able to increase root yield (Figure 5).

Cultivars with P-efficient in soils deficient in this nutrient produce high yields per unit of $\mathrm{P}$ absorbed, since they have low internal $P$ demand for normal metabolic activities and growth and, therefore, low need for mineral $P$ fertilizer inputs to produce reasonably high yield. Furthermore, they remove less $P$ from the soil during their development, resulting in a less demand for $P$, resulting in reduced costs with phosphate fertilization (Balemi and Negisho 2012).

\section{Conclusions}

The estimated doses of phosphorus that maximized marketable yield ranged from 186.8 to $243.5 \mathrm{~kg}$ $\mathrm{ha}^{-1}$ of $\mathrm{P}_{2} \mathrm{O}_{5}$, depending on the cultivar. The Native cultivar was classified as more efficient in the use of $\mathrm{P}$, as well as in the gain in biomass and marketable yield roots.

The doses that promoted greater productivity are above the values recommended by Cavalcanti (2008), confirming that fertilizer recommendations should be revised, considering the highest expected yields, cultivars, and crop density.

Authors' Contributions: JESUS, P.M.M.: acquisition of data, analysis and interpretation of data, drafting the article; GRANGEIRO, L.C.: acquisition of data, analysis and interpretation of data, drafting the article, and critical review of important intellectual content; SOUSA, V.F.L.: acquisition of data, analysis and interpretation of data, and critical review of important intellectual content; SILVA, G.A.: acquisition of data, analysis and interpretation of data; SILVA, L.R.R.: acquisition of data, analysis and interpretation of data; RODRIGUES, G.S.O.: drafting the article, and critical review of important intellectual content. All authors have read and approved the final version of the manuscript. 
Ethics Approval: Not applicable.

Acknowledgments: The authors would like to thank the funding for the realization of this study provided by the Brazilian agency CAPES (Coordenação de Aperfeiçoamento de Pessoal de Nível Superior - Brasil), Finance Code 001.

\section{References}

ARAÚJO, C., ZÁRATE, N.A.H. and VIEIRA, M.C. Produção e perda de massa pós-colheita de cenoura 'Brasília', considerando doses de fósforo e de cama de frango semidecomposta. Acta Scientiarum. 2004, 26(2), 131-138. https://doi.org/10.4025/actasciagron.v26i2.1873

ASSUNÇÃO, N.S., et al. Carrot yield and recovery efficiency of nitrogen, phosphorus and potassium. Revista Caatinga. 2016, 29(4), 859-865. https://doi.org/10.1590/1983-21252016v29n410rc

ALVES, F.A.L., et al. Efeito do Ca+ externo no conteúdo de $\mathrm{Na}^{+}$e $\mathrm{K}^{+}$em cajueiros exposto a salinidade. Revista Brasileira de Ciências Agrárias. 2011, 6(4), 602-608. https://doi.org/10.5039/agraria.v6i4a1257

AVALHÃES, C.C., et al. Rendimento e crescimento da beterraba em função da adubação com fósforo. Scientia Agrária. 2009, 10(1), 75-80. https://doi.org/10.5380/rsa.v10il.13173

BALEMI, T. and NEGISHO, K. Management of soil phosphorus and plant adaptation mechanisms to phosphorus stress for sustainable crop production: a review. Journal of Soil Science and Plant Nutrition. 2012, 12(3), 547-562. https://dx.doi.org/10.4067/S0718-

$\underline{95162012005000015}$

BASTOS, A.L., et al. Influência de doses de fósforo no fluxo difusivo em solos de Alagoas. Revista Brasileira de Engenharia Agrícola e Ambiental. 2008, 12(2), 136-142. https://doi.org/10.1590/S1415-43662008000200005

CAVALCANTI, F.J.A. Recomendações de adubação para o Estado de Pernambuco: $2^{a}$ aproximação. 3 ed. Recife: Instituto Agronômico de Pernambuco, 2008.

CAVALCANTE, R.R., NASCIMENTO, I.R. and ROCHA, R.N.C. Características produtivas de genótipos de batata doce em função de doses de fósforo em solos de terra firme no município de Carreiro, AM. Tecnologia \& Ciência Agropecuária. 2017, 11(6), 17-23.

CECILIO FILHO, A.B. and PEIXOTO, F.C. Acúmulo e exportação de nutrientes em cenoura 'Forto'. Revista Caatinga. 2013, 26(1), 64-70.

CONFEDERAÇÃO DA AGRICULTURA E PECUÁRIA DO BRASIL. Mapeamento e qualificação produtiva das hortaliças do Brasil. Brasília: CNA, 2017.

CHAVES, F.M.S., et al. Desempenho da cenoura sob diferentes doses de fósforo na microrregião de Chapadinha - MA. In: Congresso brasileiro de ciência do solo. Natal: SBCS, 2015.

CRUZ, S.M.C., et al. Mineral nutrition and yield of sweet potato according to phosphorus doses. Comunicata Scientia. 2016, 7(2), $183-191$. https://doi.org/10.14295/cs.v7i2.958

DEZORDI, L.R., et al. Nutrient demand of the carrot crop. African Journal of Agricultural Research. 2015. 10(35), 3533-3542. https://doi.org/10.5897/AJAR2015.9849

DRISSI, S., et al. Effect of zinc-phosphorus interaction on corn silage grown on sandy soil. Agriculture. 2015, 5, 1047-1059. https://doi.org/10.3390/agriculture5041047

FAGERIA, N.D. and KLUTHCOUSKI, J. Metodologia para avaliação de cultivares de arroz e feijão para condições adversas de solo. Brasília: Embrapa-CNPAF, 1980

FERNANDES, A.M. and SORATTO, R.P. Phosphorus fertilizers rate for fresh Market potato cultivars grown in tropical soli with low phosphorus availability. American Journal of Potato Research. 2016, 93, 404-414. https://doi.org/0.1007/s12230-016-9515-7

FERREIRA, D.F. Sisvar: A guide for its bootstrap procedures in multiple comparisons. Revista Ciência e Agrotecnologia. 2014, 38(2), 109-112.

FLORES, R.A., et al. Crescimento e desordem nutricional em pimenteira malagueta cultivada em soluções nutritivas suprimidas de macronutrientes. Revista Brasileira de Ciências Agrarias. 2012, 7(1), 104-110. https://doi.org/10.5039/agraria.v7i1a1648

HU, Y.F., et al. Genotypic differences in root morphology and phosphorus uptake kinetics in brassica napus under low phosphorus supply. Journal of Plant Nutrition. 2010, 33(6), 889-901. https://doi.org/10.1080/01904161003658239

MALAVOLTA, E., VITTI, G.C. and OLIVEIRA, S.A. Avaliação do estado nutricional das plantas: princípios e aplicações. 2nd ed. Piracicaba: Potafos, 1997.

MELO, P.T. and ARAÚJO, T.H., 2016. Cultivares. In: NICK, C. and BORÉM, A. (Eds.). Cenoura do plantio a colheita. Viçosa: Editora UFV. pp. 66-83. NASCIMENTO, M.V., et al. Adubação fosfatada no cultivo de hortaliças produtoras de raízes. Revista de Agricultura Neotropical. 2017, 4(1), 816

OLIVEIRA, R.J.P., et al. Calibração da adubação fosfatada e potássica para beterraba na região do Vale do Itajaí. Horticultura Brasileira. 2016, 34, 210-215. https://doi.org/10.1590/S0102-053620160000200010

OLIVEIRA, A.P., et al. Produção de batata-doce e teor de amido nas raízes em função de doses de $\mathrm{P}_{2} \mathrm{O}_{5}$. Acta Scientiarum. Agronomy. 2005, 27(4), 747-751. https://doi.org/10.4025/actasciagron.v27i4.1342 
OVA, E.A., et al. High phosphorus supply reduced zinc concentration of wheat in native soil but not in autoclaved soil or nutriente solution. Plant Soil. 2015, 393, 147-162. https://doi.org/10.1007/s11104-015-2483-8

PELÁ, A., et al. Enhanced-efficiency phosphorus fertilizer: promising technology for carrot crop. Horticultura Brasileira. 2018, 36(3), $492-49$. https://doi.org/10.1590/S0102-053620180411

PÉRET, B., et al. Root developmental adaptation to phosphate starvation: better safe than sorry. Trends in Plant Science. 2011, 16(8), 442-450. https://doi.org/10.1016/j.tplants.2011.05.006

REGO, L.G.S., et al. Pedogenesis and soil classification of an experimental farm in Mossoró, state of Rio Grande do Norte, Brazil. Revista Caatinga. 2016, 29(4), 1036-1042. https://doi.org/10.1590/1983-21252016v29n430rc

RESENDE, G.M. and BRAGA, M.B. Produtividade de cultivares e populações de cenoura em sistema orgânico de cultivo. Horticultura Brasileira. 2014, 32(1), 102-106. https://doi.org/10.1590/S0102-05362014000100017

TRANI, P.E. and RAIJ, B.V., 1997. Hortaliças. In: RAIJ, B.V., CANTARELLA, H., QUAGGIO, J.A. and FURLANI, A.M.C. (Eds.). Recomendações de adubação e calagem para o estado de São Paulo. 2nd ed. Campinas: Instituto Agronômico/Fundação IAC.

ZANFIROV, C.A., et al. Produção de cenoura em função das doses de potássio em cobertura. Horticultura Brasileira. 2012, 30(4), 747-

750. https://doi.org/10.1590/S0102-05362012000400030

Received: 24 April 2020 | Accepted: 30 August 2020 | Published: 29 December 2021

This is an Open Access article distributed under the terms of the Creative Commons Attribution License, which permits unrestricted use, distribution, and reproduction in any medium, provided the original work is properly cited. 